\title{
Chapter 10 \\ Defining 'Responsible' in Responsible \\ Research and Innovation: The Case \\ of Quadruple Helix Innovation \\ in the Energy Sector in the Tampere Region
}

\author{
Yohannes Mehari, Elias Pekkola, Jonna Hjelt, Yuzhuo Cai, Jari Stenvall, \\ and Francisco Javier Ortega-Colomer
}

\begin{abstract}
This paper aims to investigate the social innovation process in the innovation ecosystem of the Tampere region, taking the energy sector as an example. It focuses on analysing how responsible research and innovation (RRI) activities are understood by regional stakeholders, particularly regarding how the roles of different actors (universities, public agencies, industry, and citizens) are constituted, and how different actors facilitate social innovation. The research questions are approached by the conceptual framework of Quadruple Helix which is useful for understanding the roles of citizens and interwoven fabric in innovation ecosystems, including social innovation. Empirically, the paper is based on analysing qualitative interviews with 12 stakeholders in the energy sector in Tampere. It is supplemented by analysing national and regional documents related to energy policies and the role of research and universities as well as citizens in sustainable (economic) development. Based on our findings the responsibility in research and innovation activities is not defined by utilising existing conceptual approaches or EU policies, such as RRI.
\end{abstract}

Keywords Responsible research and innovation (RRI) - Quadruple helix · Citizenship · Energy sector

\footnotetext{
Y. Mehari $(\bowtie) \cdot$ E. Pekkola $\cdot$ J. Hjelt $\cdot$ Y. Cai $\cdot$ J. Stenvall

Faculty of Management and Business, Administrative Studies, Tampere University, Tampere, Finland

e-mail: yohannes.mehari@tuni.fi; elias.pekkola@tuni.fi; jonna.hjelt@tuni.fi;

yuzhuo.cai@tuni.fi; jari.stenvall@tuni.fi

F. J. Ortega-Colomer

Department of Management, Faculty of Economics, University of Valencia, Valencia, Spain e-mail: Javier.Ortega@uv.es
}

C. Păunescu et al. (eds.), Social Innovation in Higher Education, Innovation,

Technology, and Knowledge Management,

https://doi.org/10.1007/978-3-030-84044-0_10 


\section{The Key Points of the Chapter Are the Following}

- Research and innovation systems are being challenged by global forces in terms of knowledge, social networks, technology, and innovation.

- From a quadruple helix perspective, citizenship's voice is key to RRI policies, but it entails a big challenge.

- The paper provides empirical evidence on how different stakeholders understand RRI activities in achieving social innovations.

- We conclude that democratic solutions are enabling social participation to solve collective problems, like on energy.

\section{Introduction}

Finland has been regarded as a model case of the knowledge economy, characterised by its greater dependence on specific key assets, such as knowledge, information, and high quality of education to which business and public bodies increasingly require access (Dahlman et al., 2006). Since the 2000s, Finland, among other Nordic countries, has been ranked at the top of the lists in conditions of the quality of the life of the citizens (Miettinen, 2013). The existence of a 'virtuous cycle' between strong education, the welfare society and economic development has been pointed out as its main source of national competitiveness (Castells \& Himanen, 2002). However, this relative success of the Finnish national research and innovation system is being affected by changes at the global scale in terms of key driving forces: knowledge, social networks, technology, and innovation (Schienstock \& Hämäläinen, 2001). This calls for a deep reflection not only on how universities can cope with such global challenges from within and from outside, but also on how civil society can participate in such a debate. Mostly due to the digital transformation, the technological environment is changing rapidly (Appio et al., 2021). Changes are not only technological but increasingly social and institutional (Boschma, 2005), which explains why such new economic possibilities - for instance, through digitalisation and business model innovations, that in turn have radically changed the economic field-are expected to be also socially innovative (Dahlman et al., 2006; Karhunmaa, 2019; Şener \& Sarıdoğan, 2011; Schienstock \& Hämäläinen, 2001).

Hence, the ability to understand technological possibilities and to figure out how to ease the means by which to collaborate and to create value are essential (Ritala \& Hurmelinna-Laukkanen, 2009); likewise, so is the need for better co-operation between the actors at regional levels (OECD, 2017: 21). The changing dynamic in innovation processes can be captured by the concepts, such as Responsible Research and Innovation (RRI) and the Quadruple Helix, both of which are aimed to bridge the gap between society and research actors in order to achieve sustainable development. The RRI concept has become popular across Europe and the world, over the past few decades (Owen et al., 2012). The term RRI has been brought to the fore by policy makers and funding agencies, as a cross-cutting issue of the European Commission (EC) Horizon 2020 programme that aims at bridging the gap between 
society, research, and innovation (de Saille, 2015). Indeed, the term RRI was introduced to avoid the reductionist view of purely technological innovation (Burget et al., 2017). RRI has also attracted the attention of academic scholars over the past decade. As such, various attempts have been made to establish a comprehensive conceptual framework that guides its core dimensions (Stilgoe et al., 2013; Yaghmaei, 2018). In the last two decades, there has been a growing role of citizens in contributing their points of view on ethical problems, such as risk management and legal aspects and socioeconomic issues related to new technologies, which give way to a change in paradigm for 'public understanding of science' (Hennen, 2013). From a policy perspective, one key milestone is found in the call for dialogue of the European citizen in 2001 (EC, 2001), where the promotion of participatory processes of technology assessment was key to underpin "public debate, knowledgesharing and scrutiny of policy makers and experts", in areas like genetically modified food (Zhao et al., 2015).

Nevertheless, numerous studies show that RRI lacks clarity and definition, both in concept and practice (Owen et al., 2013). It appears that our understanding of RRI is largely guided more by project-based administration definitions than by widely accepted academic definitions, a finding that is supported by rigorous empirical evidence (Burget et al., 2017). This in turn has led to multiple and yet divergent perceptions and interpretations of the core concept of RRI and the role of practitioners in its implementation (Owen \& Pansera, 2019). In addition, studies show that "less effort has been given to the empirical investigation of how RRI is perceived and practised" (Christensen et al., 2020, p. 361).

Therefore, the research question of this paper is how responsible research and innovation activities are understood by regional stakeholders? The answer to this question is key to understand the roles of different actors (universities, public agencies, industry, and citizens) in RRI activities in achieving social innovations. The chapter explores the case of the Tampere region's social innovation process in the energy sector. Specifically, the focus is on how different stakeholders understand the concepts of 'innovation' and 'responsible' in the context of the quadruple helix.

The chapter is organised as follows. The next section summarises the perspective of the Helices on RRI and stakeholders. The third section describes the perceptions of different actors on RRI. The fourth section presents the methodology used, followed by a description of the data. The results are shown in the fifth section. Finally, we discuss and conclude the main results obtained in the sixth section.

\section{RRI and Stakeholders: The Perspective of the Helices}

The concept of RRI was originally introduced by René von Schomberg (2001), working for the Governance and Ethics Unit of the European Commission. Thus, RRI was originally proposed as a policy concept around which academic discussions have been initiated. Probably because of the use of the concept in the Commission's funding instruments RRI was defined mainly from an administrative perspective 
(von Schomberg, 2001). Next. the concept has been embedded to EU-Horizons 2020 funding instrument and thus the vocabulary of it has been widely (and sometimes forcedly) used. Yet, the basic questions responsible for what? and to whom? are questions which are still difficult to operationalise at the EU level as well as in local contexts.

However, such an administrative approach to define the term RRI has been criticised for lacking depth and not being effective in guiding scholarly research on the theme (Burget et al., 2017). Based on a comprehensive review of the literature dealing with RRI, Burget et al. (2017) provide a more academic definition of RRI.

\begin{abstract}
RRI is an attempt to govern the process of research and innovation with the aim of democratically including, early on, all parties concerned in anticipating and discerning how research and innovation can or may benefit society. 'Anticipating' means that there should be an imaginative effort in trying to see how a piece of research or a product could evolve in the future. 'Discerning' means that one should always apply judgment to see if the future 'imagined' is something desirable and act accordingly.
\end{abstract}

Consequently, RRI, both from an administrative and from an academic viewpoint, contains the idea of involvement of societal stakeholders in the process. Hence, RRI is more than a standard or a procedure by which to reach desired goals. Based on these approaches, the citizens and other societal actors play a key role in research and innovation activities, not only as legitimisers (participants and users), but also as co-producers.

To deeply understand RRI, one has to take into account that it does not emerge from out of the blue. It has a strong family resemblance with many other innovationrelated concepts and descriptions of changes in society, e.g. in the transition from innovation systems (Lundvall, 1992) to innovation ecosystems (Carayannis et al., 2018). Compared to innovation systems, the concept of an innovation ecosystem accentuates the ecologic aspect, sustainable dimension, co-creation processes and co-innovation networking in cross-geographical contexts (Cai et al., 2019; Cai \& Etzkowitz, 2020). As such, recent theoretical elaborations on innovation ecosystems may provide the most relevant analytical tools for empirical studies on issues related to RRI.

In such context, Carayannis and Campbell (2009) proposed the Quadruple Helix model of innovation as an conceptual tool to analyse actors and their interactions in an innovation ecosystem. The Quadruple Helix model was developed by incorporating the public or civil society as the fourth helix into the Triple Helix model of university-industry-government for innovation and entrepreneurship, originated by Etzkowitz and Leydesdorff (1995).

While the Triple Helix represents a basic core model of innovation for the knowledge economy, the Quadruple Helix describes the knowledge society and knowledge democracy. This corroborates other scholars' observation that the Quadruple Helix model has been considered more suitable for addressing new features in the knowledge production and innovation processes that are characterised by RRI and the participation of citizens (De Oliveira Monteiro \& Carayannis, 2017; Miller et al., 2018).

In this paper, we use the Quadruple Helix approach to direct our focus from individual projects and RRI activities towards the more 'systemic' understanding of 
RRI and especially the role of different stakeholders in the definitions of 'responsible' and 'innovation' in the regional innovation environment. In the next section, a discussion of the role of different actors, forming the quadruple helix, in RRI is presented.

\section{An Analytical Framework: Perceptions and the Role of Stakeholders in RRI}

This section informs the analytical framework of the study. It briefly touches upon previous analyses of different actors' perspectives on RRI. It specifically focuses on how actors, as explained in the Quadruple Helix, perceive their roles in promoting RRI, define the concept of 'responsible', and understand the social innovation processes. The focus on investigating the perception and practices of stakeholders in RRI is mainly because there is dearth of empirical evidence on how RRI is perceived and practised by the main actors (e.g., see Blok, et al., 2015; Christensen et al., 2020). The analytical framework of the study is guided by the Quadruple Helix framework that postulates the dynamic participation and interaction of university, industry, government, and the public in innovation processes.

\subsection{RRI in Higher Education Institutions and Research Institutes}

Studies show that RRI is gaining central ground in core missions of Higher Education Institutions (HEIs, hereafter). The increasing impact of scientific innovation in society necessitates the need for greater public accountability, participation, and responsibility (Bozeman \& Sarewitz, 2011; Stilgoe et al., 2013). HEIs are now under constant pressure to align research with societal needs and to create systems in which public agents participate in research processes, which are guaranteed by the increased public influence on setting research agendas and evaluating the social impact of research results. However, the process of including RRI in HEIs' strategic plans have shown mixed results, both in perceptions and practical dimensions.

The perception of the academic community towards the concept and implementation of RRI in HEIs and its role could be seen from two conceptual perspectives: 'science for society', also known as 'product-oriented RRI', in which the product of research is determined by its practical urgency and social desirability, and 'science with society', which is 'process oriented' and whereby public participation is emphasised in the process of research (Macnaghten, 2016; Stilgoe et al., 2013; \& von Schomberg, 2011). A study conducted by Carrier and Gartzlaff (2020) elucidated that the scientific community have shown a positive attitude towards the emergence of RRI as strategic actions of universities. They tend to view their interactions and roles with society as responses that emerge from commitments to public duty and accountability (Burchell, 2015; Carrier \& Gartzlaff, 2020). 
Under the perspective of 'science for society' and despite having a positive perception, the academic community has raised important concerns about the involvement of public agents in research and innovation processes. For example, there are fears that the efforts to provide unfettered access to the 'uninformed' public agents would result in 'bias of societal agents' in the research and innovation processes that could jeopardise the integrity and acceptability of the research results and innovation products. In other words, the academic community 'tend to perceive the general public as lacking the knowledge necessary for understanding research findings' (Carrier \& Gartzlaff, 2020, p. 151). Therefore, for the academic community, the role of HEIs in public commitment should largely focus on science education and the dissemination of information (Carrier \& Gartzlaff, 2020). Similarly, the perspective of 'science with society' is associated with the belief that increasing public accountability may endanger academic freedom and the institutional autonomy that academia and universities have enjoyed for years. In addition, researchers hold the view that the mere focus on public accountability and social desirability would only excel at the expense of basic research by RRI procedures.

\subsection{RRI in Industry or Business}

The emergence of RRI as a new concept has brought opportunities and challenges to industries and businesses in their roles in society and the environment in which they function. On the one hand, there is the rapid pace of innovation and the pressures industries face to remain competitive in the market; on the other hand, there are the pressures to 'maintain public trust through innovation that generates both social value and economic returns' (Martinuzzi et al., 2018) and has created extra pressures to main the equilibrium between keeping efficiency and social values. In the context of industry, research and innovation can be responsible if they meet the standards set for environment, ethics, social value and politics.

Although there is now a large body of academic research on RRI, it is struggling to have an effect on the industrial community, since many of the principles, taxonomy, methods, and methodologies are not compatible with current industrial practices (Dreyer et al., 2017). This appears to create misunderstandings and disagreements between the parties as to where and how industry fits into the central tenants of RRI (Dreyer et al., 2017). For example, the engagement of industries in sustainable and positive societal impact activities are to be recognised by RRI researchers, nor is the research on RRI fully adopted by industry. In other words, the industry community perceive that RRI researchers follow a reductionist approach that disregards ongoing work in related fields and therefore fails to have an impact on innovation governance (Dreyer et al., 2017). Accordingly, from the perspective of the industry or business community, the current RRI framework does not properly reflect established business practices on innovation and fails to observe parallel development such as the debates of CSV and CSR (Dreyer et al., 2017).

Even though the relationship between RRI and industries or businesses is not guided by a clearly and comprehensively established framework, some of the central 
themes-such as industry or business motivations for adopting RRI, the state of implementation of concrete RRI practices, the role of stakeholders in responsible innovation processes, as well as drivers and barriers to the further diffusion of RRI in industry-have attracted the attention of researchers and practitioners (e.g., see Martinuzzi et al., 2018), and these highlight the relevance of RRI for industries (Chatfield et al., 2017).

\subsection{RRI and Public Policy Actors}

Under the umbrella of the policy structures of the European Union (EU), the concept of RRI focuses on a 'new social contract' establishing a 'shared responsibility between science, policy and society', to pave the way for science to contribute to societal development (de Saille, 2015; EC, 2009). Within the principle of RRI, the emphasis on relating science and society is considered a paradigm shift from the 'republic of science' (Polanyi, 1962) model that advocates for the separation of science and political, social and ethical values, to the rather systematically interrelated approach in which science and society are seen as complementary and supportive of each other for the betterment of society (Sturgis \& Nick, 2004; de Saille, 2015). In general, studies show that, even though most organisations are unfamiliar with RRI, they 'employ diverse perceptions of responsibility and mechanisms to promote it' (Christensen et al., 2020, p. 360).

\subsection{RRI in Citizens and Civil Societies}

The participation of citizens and civil societies in RRI, also commonly known as public engagement, involves cocreating the future with the public and civil society organisations that deliberate on issues of science and technology (EC, 2009). The focus is mainly on creating the platform for ethical value-laden issues to be explored and targets for inclusiveness, transparency, diversity, and creativity to be incorporated into the RRI process (EC, 2009). Societal engagement is a key pillar of RRI that focuses on making science, technology, and innovation relevant, transparent, interactive, and responsive (Bauer et al., 2021). Proponents of RRI argue that, not only does RRI balance the economic imperative of innovation with societal needs and expectations (Owen et al., 2013; Von Schomberg \& Blok, 2019), but it also advocates for societal engagement in research and innovation processes (Burget et al., 2017).

Even though societal or public engagement is the central dimension of RRI, studies show that the concept lacks clarity in terms of use, requirements, and application (Bauer et al., 2021). Underlining this gap, Bauer et al. (2021) identified five key dimensions that frame the requirements and challenges for societal engagement in RRI processes. These distinct dimensions are comprised of the purpose of 
societal engagement (de Saille, 2015), who to engage (Strand et al., 2015) when the engagement occurs (Asante et al., 2014), how to engage (Asante et al., 2014), and the framing of STI in engagement processes (de Saille, 2015). As a result, Bauer et al. (2021) concluded that the main purpose of societal engagement in RRI is to target the improvement of citizens' participation in STI decision-making processes. To do this, they call for inclusiveness or a balanced view of all actors who are affected by the process. In addition, they underlined continuous engagement and a two-way communication between experts, stakeholders, and citizens. Finally, they underscore the importance of preserving ethics, societal needs, values, and concerns in the overall engagement processes in RRI. Bauer et al. (2021) identified two key challenges in advancing societal engagement in RRI: politicisation of S\&T, and new interpretation of the often-lamented ineffectiveness of participation.

As shown in Table 10.1, the four major actors show subtle differences in their perception of responsibility in the context of RRI (Christensen et al., 2020). The major differences appear to rest on their implementation approach of RRI. For example, academics define 'responsible' from their internal perspective that is 'quite formalised and internally focussed in their effort to promote responsible research, but a large proportion of them also host or support open science events' (Christensen et al., 2020, p. 368). Academics view responsibility from the prism of 'duty that arises from taking public money' (Carrier \& Gartzlaff, 2020, p. 151), however, they see the general public as 'ill informed, irrational and biased', and thus public participation in research and innovation processes should be limited to specific tasks, such as science education and dissemination events (Carrier \& Gartzlaff, 2020, p. 151).

The perception and role of businesses and industries in RRI are guided by two important challenges the sector has faced: the rapid global race to innovate to maintain competitive advantage (Herrera, 2015), and the efforts to win public trust in business (Bies, 2014; Martinuzzi et al., 2018). Like universities, businesses and industries tend to be internally focussed and more likely to formalise their efforts in organisational strategies. In other words, they synchronise principles of responsibility in their strategies and policies. Therefore, business and industries define RRI as an effort to find sustainable solutions that are environmentally friendly, ethically acceptable, socially valuable processes of research and innovation (Chatfield et al., 2017; Christensen et al., 2020; Dreyer et al., 2017; Martinuzzi et al., 2018).

Even though the importance of public engagement in RRI receives support from policy makers and researchers, there seem to be differences on the ethical and societal aspects of the goal of innovation practices that should be achieved responsibly (Blok et al., 2015). Unlike industries and universities, citizens or civic organisations tend to be outward oriented in their approach to RRI. Citizens or civic organisations focus on collaborating with others, hosting science events, engaging in campaigns and advocacy to influence policies (Christensen et al., 2020). Therefore, citizens view their role in RRI as continuous engagement and a two-way communication between experts, stakeholders, and citizens (e.g., Owen et al., 2013; Von Schomberg \& Blok, 2019); they define the concept of 'responsible' in relation to cocreating the future with the public and civil society organisations with 


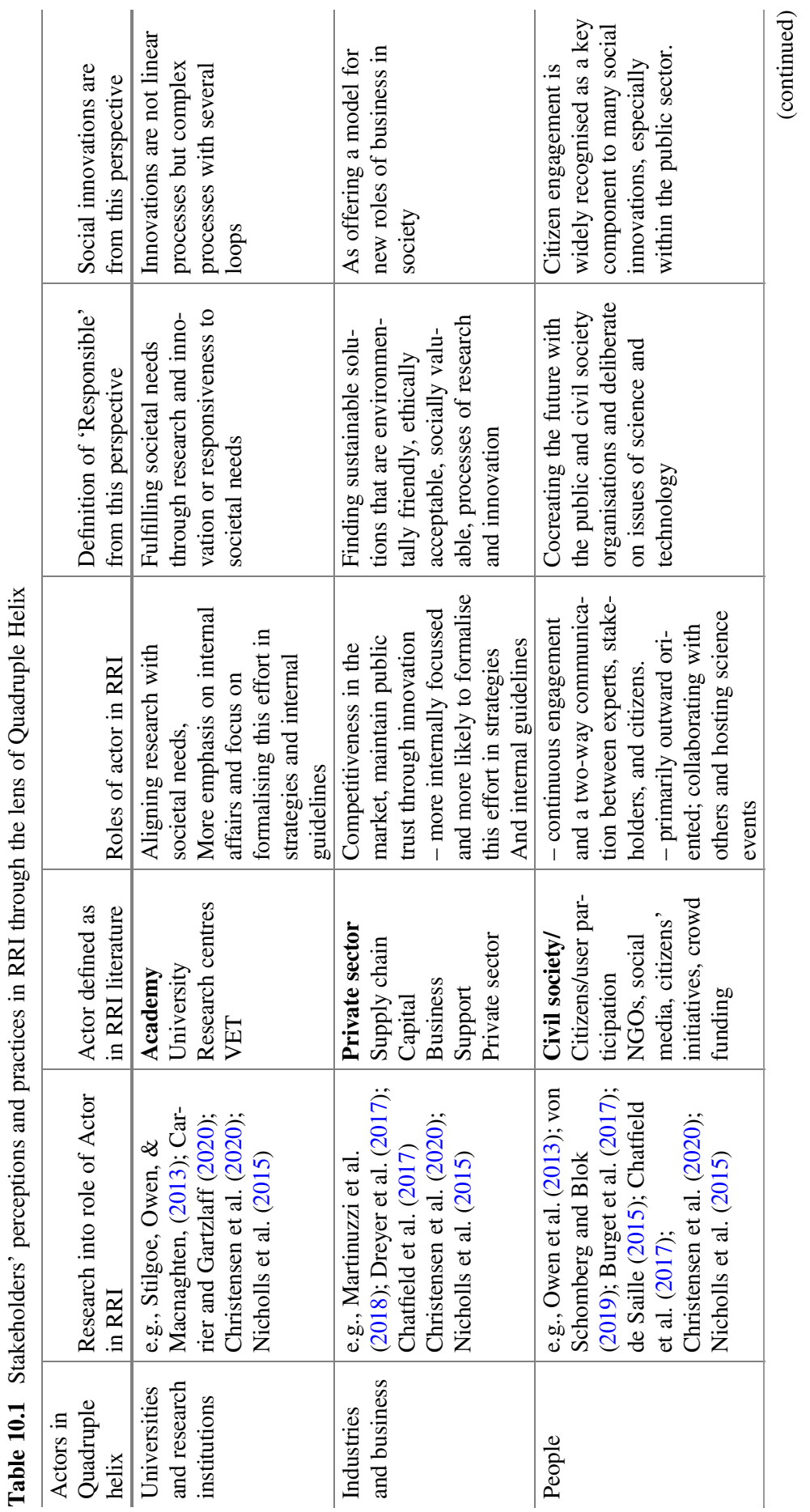




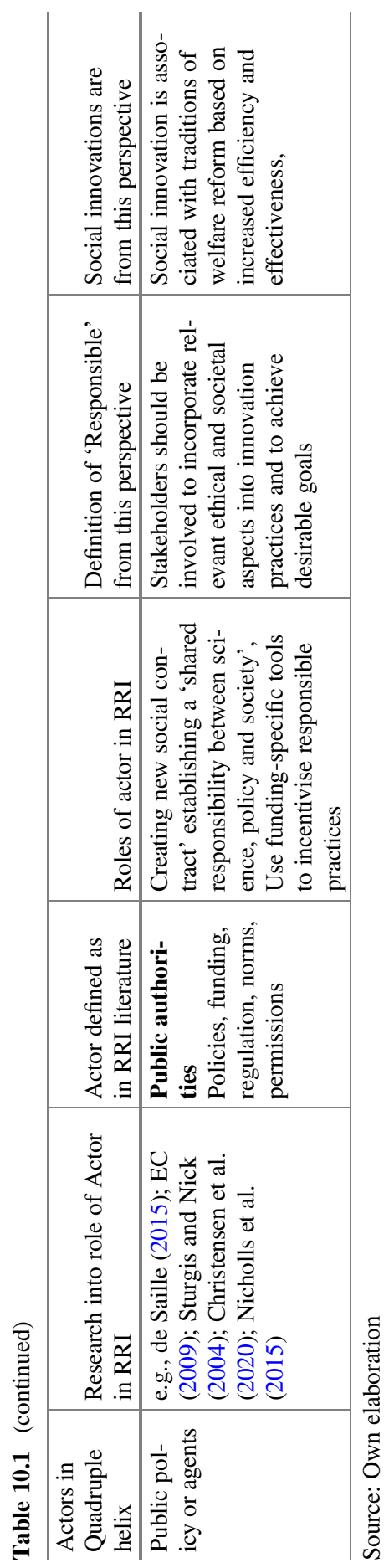


which they deliberate on issues of science and technology (Burget et al., 2017; Chatfield et al., 2017; Christensen et al., 2020; de Saille, 2015).

Empirical studies show that public policy agents or governments have been concerned about research practices and its results. Specifically, they focus on aspects of ethics as well as transparency and Open Access. (e.g., see Christensen et al., 2020). Their role in promoting RRI practices is mainly guided by the position they hold as funders. For example, they are keen to set standards of responsibility-related requirements for applicants in funding application processes. They encourage applicants that focus on research integrity, RRI, gender equality, ethics, Open Access publishing or public engagement events (Christensen et al., 2020). In other words, they use funding-specific tools to incentivise responsible practices. Therefore, for public policy makers, the concept of 'responsible' is ensured when stakeholders are involved in incorporating relevant ethical and societal aspects into innovation practices and achieving desirable goals (e.g., see Christensen et al., 2020; de Saille, 2015; EC, 2009; Sturgis \& Nick, 2004).

\section{Method and Data}

The empirical data is collected in part as an EU-funded project in Responsible Research and Innovation Learning (RRIL), of one-year duration, comprising a consortium of universities from Finland, Poland and Spain: Universitat Rovira i Virgili, Spain; Tampere University, Finland; Kozminsk University, Poland. RRIL focuses on the development of three learning modules: public engagement, gender equality and ethics (in the knowledge fields, energy and economy), and testing the learning modules in innovative environments based on interactive real-problem approaches.

The method used in this report follows qualitative evaluation research; research material has been analysed for content. Qualitative content analysis is theorybounded, based on data collected through interviews. Interviewees were from higher education, public research institutes, business, city and region. The interviewees were not part of project but were considered as possible beneficiaries of the project out comes. These interviewees offer helix perspective to the RRI in energy sector and evaluate the possible roles and impacts of citizens involvement. Theory follows the RRI definition and has been used as a framework for thematic and semistructured questionnaires. The aim was to evaluate how the RRI concept is known and used in R\&I practice or what kind of other concepts or policies are used.

The data is collected from 12 interviewees in a cross-sectional study. Interviews were made during October to December 2019 and analysed during the same period. Interviewees were from the city and region (3), companies (3), universities (4) and public research institutions (2). The time for one interview was approximately one hour. Interviewees were from the Tampere region and were selected based on different professional knowledge areas and understanding of research and innovation in practice. More detailed information on the interviewees can be found in 
Appendix 1. The questions were semi-structured, using thematic analysis. The questions were the same for all interviewees and followed the same order. The study was conducted mainly in the context of energy-related business, using RRI as a framework.

In addition to the semi-structured interviews, a document analysis related to the national and regional innovation systems is conducted. Moreover, a discussion on the national innovation system is presented since Finland is a small nation and regional actors are closely connected to the national system, and the distinction between the national and regional innovation systems is difficult to make. The documents analysed for this paper are listed in Appendix 1.

\section{RRI in the Quadruple Helix of Innovation in the Tampere Region}

\subsection{The Roles of Stakeholders in Finnish National Innovation}

Typical for Finland is that it has one of the largest numbers of researchers (OECD, 2017) and the funding for instance for universities and overall, to the R\&I comes predominantly from the government. (OECD, 2017). The Finnish government has declared its strategic goal of promoting Finland as the most competent environment for innovation and experimentation by 2030. The intention is to enhance the knowledge base, to develop knowledge platforms and growth ecosystems and to encourage companies towards internationality (Valtioneuvosto, 2019). Strategic implementation is required in the regions where innovation actors interact and create close networks between universities, research centres and companies (Pirkanmaan liitto, 2017). The main actors in the Finnish innovation systems are large companies and public sector municipalities, although there have been efforts to promote involvement of small and medium-sized enterprises (SMEs, hereafter) around growth and internationality (Tilastokeskus, 2017a, b, 2018).

Public sector is involved in development of research and innovation activities in all levels of governance from the cabinet of ministers to local government. The Research and Innovation Council is the Finnish government's advisory body, which is responsible for the strategic development and coordination of the Finnish national innovation system as a whole. The Council promotes the R\&I policy that supports the Finnish wellbeing, growth and sustainable competitiveness in global competition (OECD, 2017; Dahlman et al., 2006; Valtioneuvosto, 2019). The Ministry of Education and Culture is responsible for higher education and for policy targets in science together with Academy of Finland (that is a semi-independent state agency under the Ministry) as well as development higher education policies together with the universities and polytechnics. Nationally, Finnish cities and municipalities are expected to promote a business-friendly environment, and the Ministry of Economic 
Affairs and Employment and its regional branches encourages companies to embrace sustainable growth and productivity (Työ- ja elinkeinoministeriö (TEM) 2019; 2019/1; 2019/2). Business Finland functions as the Ministry of Employment and Economy and accelerates the global growth of companies and their ability to foster international growth and ecosystems (Dahlman et al., 2006; Business Finland, 2017). In Tampere region the most important actor is the city council of Tampere.

As important part of innovation system Finland has 12 research universities, 22 universities of applied sciences all funded publicly. Prior 2019 there were three HEIs in Tampere region. Currently all institutions are operating under one foundation as a university of applied sciences and as a merger university formed from former technical university and comprehensive university. In addition, there are several governmental research institutions that promote research and innovation. These include the Technical Research Centre (VTT), the Natural Resources Institute (LUKE), the National Institute for Health and Welfare (THL) and the Government Institute for Economic Research (VATT). In the Tampere region, VTT is an influential actor in R\&I efforts among multidimensional universities.

Business is mentioned as one of the main platforms for R\&D activities and one of the main beneficiaries of the national innovation system, as a knowledge and competence user as well as the main dynamo keeping innovation activity and production alive. In Finnish industry structure, large companies are very influential even though there have been efforts to enhance the influence and number of SME. The work is still ongoing, as there have not yet been sufficient changes. Moreover, in Finland there are only a few large companies and they operate in quite narrow industry sectors. The need to widen industry sectors and the number of companies is very essential to Finland (TEM, 2014, 2018, 2020; Tilastokeskus, 2005, 2017a, b, 2018; Valtioneuvosto 2019). Companies are often seen as beneficiaries of different funding instruments and as a representative of 'society' as well as 'economy'.

\subsection{The Aim of Tampere Innovation Activities and the Role of Stakeholders in Regional Innovation Strategy}

The primary goals of the city of Tampere's R\&I strategy are to promote a closely defined green, international and low-carbon community structure through sustainable development, digitalisation and an innovation ecosystem, in which both citizens and businesses can grow and achieve well-being and an improved lifestyle. This is a fertile area in which to cultivate social innovations and move forward from technological possibilities to producing service content based on new technologies and technology architectures. The vision for the city of Tampere by 2025 is that Tampere will be 'superior in regeneration-sustainably growing'.

The strategic goals are to diversify and renew business activities and to increase R\&I investments. It is also important to ensure that the economy has the necessary knowledge and capabilities to increase its ability in creating world-class companies 
and an innovation ecosystem. Business Tampere, the region's economic development agency, is promoting goals with the aim of working as a platform for different networks. For instance, the Business Tampere programme, 'Smart Tampere', promotes energy renewal and has the primary goals of impacting climate change positively and developing energy efficiency.

In order to meet sustainable solutions, the R\&I system requires better co-operation between actors at regional levels (OECD, 2017). For instance, in the Tampere region there is a type of living lab method called Hiedanranta, which involves an innovation platform in the Tampere area. Different actors are involved in this project platform, including companies, citizens, civil servants and researchers, who, together, aim to create sustainable living conditions. There are also platforms on which companies can create businesses and promote growth through special networks, such as Demola, which connects companies, researchers and students from the universities and polytechnics, in creating new solutions to various problems in which the regional authorities are interested. However, it seems to be quite difficult to get citizens involved in a reliable and valid way. Social innovationsnew ways to get together and for people to connect-may be needed to achieve this interaction (Pirkanmaan liitto, 2014).

\subsection{Responsible Research and Innovation in a Helix: a Stakeholder View}

From analysing the interviews, an emphasis is put on how the different actors of the regional innovation system perceived their own role and the role of other actors in RRI, how they define 'responsible' and what their overall understanding is of the social innovations.

Interviewees from the business (industry) perspective defined responsibility as the ability to ensure energy delivery for customers and keep up functioning systems. Customers represent civil society at large, because energy companies' infrastructure is not competitive, although energy sales are; additionally, there are different kinds of customers, such as households, industries, the public sector, and, moreover, the city of Tampere is a company owner. Therefore, directly and indirectly, customers are also taxpayers. The energy company is an interesting example of an actor in a helix that does not easily fit into its own column. It could be analysed as a helix unto itself. It is publicly owned and thus steered by the political dimension in the form of an owner. It is operating as a limited company but producing both public good via monopoly (energy transmission) and private good via the competitive market (energy production). It has an historical and cultural heritage by which to consider its customers as more than customers-namely, as citizens and residents of the region.

From these multiple linking connections, energy impacts all our lives and comes to surface if something goes wrong. Among customer perspectives, and because of 
how energy industries intertwine with the public sector, the interviewee underlined that responsibility is not only the ability to diminish costs and use taxpayers' money in responsible ways, but also to choose responsible partners for research and innovation projects.

Our business is long-term service business, [..] partners must be responsible then [..] we [..] partner and our customers [..] will three times win, win-win-win, and it is responsible action. (H5 business)

Therefore, the innovation process should be transparent, from goals to conclusions.

From an ethical point of view, it is essential to foster transparency about who manages and leads the research and innovation and what are the estimated impacts to society at large. (H6 business)

We solve companies' problems [..] If public money is involved, [..] then it is essential to justify how it will impact, what is the social point [..] that there is no impact, also justify. (H8 academy)

The company's responsibility is also declared in its strategy, where the mission is to impact climate change through diminishing carbon emissions. This allows the company to promote innovation projects that develop solutions to tackle these kinds of wicked problems. This has had an impact on the company's evaluation of possible stakeholders and the clear focus on goals in innovation processes.

As mentioned, in the energy sector the real wicked problem is to respond to climate change; therefore, there is the increasing need for multidimensional approaches to define and create, e.g., green or renewable energy solutions. In Finland, it is typical that research institutions hold good reputations for responsibility in research and innovations among companies. This is a good starting point for the quadruple helix of research and innovation.

If we want to add responsibility, then in practice we should make more collaborative research. Co-operation in research. And the most effective way is that private money lead and public money support. In this kind of model, the resource base is comprehensive. In my opinion, in the public-private-partnership model, the responsibility is at its height. (H6 business)

However, problems occur when there is a conflict of interests between the needs of companies to innovate and those of researchers to promote basic or applied research. Sometimes, defining the problem from different perspectives or interests seems irrelevant.

We already have almost all solutions. [..] but what we need is changes in human behaviour and in political processes. (H12 academy)

Interviewees from the public agency (city council) perspective defined responsibility through social diversity in regional areas. Moreover, responsibility constituted sustainable solutions to environmental questions such as carbon emissions and circular economy. The typical, reductionistic approach to the responsibility issue was the United Nations (UN) Sustainable Development Goals (SDGs, hereafter), which is such a large concept, with 17 approaches, that it cannot be used as a practical tool. There should be useful strategic choices allowing for concentration in 
one area, e.g., environmental, economic or social questions, even though in the background other ethical dimension are also relevant. It is noteworthy that city officials do not mention RRI or commission policies but rather refer to more global UN-driven policies. I.e., in a city council, such as that of Tampere, a forerunner in knowledge-based development and university collaboration, RRI as a policy concept is not well known and thus does not have even reductionistic usage.

It is surprisingly difficult to promote sustainable road maps. It needs hard work. (H11 public agency)

Moreover, there are no indicators to support responsibility in daily work, hence such questions are on the public agencies' own duty. In some projects, reporting on participants' gender is expected, and, in every project, it is expected that stakeholders have decent records of salary and tax payments; most of the time, however, ethical issues are the public agencies own interests. In other words, public actors consider the responsible attitude as part of their daily work and value base; thus, if they are involved in RRI activities, the responsible approach is taken into account, at least for their own part. Also, public agencies thought that the quadruple perspective can provide added value for innovation activities, if research, public agencies and companies work together to produce solutions to different issues. However, they have also noticed that research interests and the practical needs of business partners or civil servants can sometimes be quite faraway from each other. The time horizon and timetables or priorities may differ over time.

For instance, in some issues it is efficient to solve practical questions between public agencies and companies, but the living lab area provided by the city of Tampere has been useful for university projects and the ability to achieve funding for research. Even though the benefits of the living lab area are obvious to the co-operators, there are civil servants in the city of Tampere who do not always see those benefits in the short-term needs and might question the willingness to maintain the area. In these kinds of problems, it is essential that large companies make positive statements about co-operation, as this is highly relevant to civil servants keeping up the living lab conditions.

In many times from the beginning the aim is that research, companies, and cities co-operate. Because if you leave some of these out, the problems may occur. Between cities and companies, the process is more straight forward and sometimes needed, but if the city leaves companies out, then the ambition may be quite high level. (H3 public agency)

From a public agency point of view, it is easier to work with companies than with universities, the ambitions of which do not always resonate with practical needs. In daily work, public agencies are expected to reveal understandable results, a point made difficult by the different time horizons between research and development. Interviewees from research (academia) defined responsibility as a way to work, beginning from selection of partners and transparency in work practices.

Transparency to the partner selection, to the interaction, how to work together, [..] that things are transparent, processes are transparent. (H2 academy) 
There are no institutional or regulative sanctions for lack of responsibility, but we have a community system where these practices of responsibility are adopted. Responsibility is realised in a good way when co-operation in wicked problems is multidimensional.

Our challenges, problems, issues [..] major societal issues [..] are that kind of that anybody cannot solve themselves. So, the only way is that we have to work together. (H10 public agency)

Many interviewees pointed out that in Finland the typical approach to renewing society is quite often technologically oriented. Now, in the midst of digital transformation, technological approaches are highly relevant and therefore many interviewees underlined the need for a multidimensional approach. For instance, in Finland, in technological research there should be also social and humanistic perspectives, to keep in mind that solutions are made for the people and with the people. In this respect, a multidimensional approach is justified. Ethical acceptance, desirability and sustainability should be featured more than they currently are, with the social impact of technological solutions as the goal. The ex-ante evaluation in this respect is valuable.

It is important that desirability is included (in innovation processes), because in traditional user-centric research there has been acceptability dominance-perspective. (H4 academy)

As quadruple perspective researchers point out, it is important that research questions answer practical needs, and that knowledge is created in co-operation. New knowledge can be used in planning processes in the city of Tampere and in business developing processes, although researchers recognise that time horizons and tables differ among actors. In this respect, researchers can support actors and organisations in change processes and bring ambitious visions, knowledge and competence to the co-operation. To foster co-operation and to ground it in practical ways, the interviewees mentioned that a living lab type of social innovation is a good example of fostering the quadruple helix approach in research and innovations.

Also, in Finland there are different kinds of innovation platforms like Hiedanranta and Satama in energy field. (H1 business)

The important starting point is to create an ambitious vision for the desired goals, define problems in multidisciplinary ways and allow pilots, experiments and collective learning in living lab areas. The government's role is to provide this kind of area and facilitate actions based on, e.g., new green solutions in energy, or circular economy solutions in business, or social diversity in society.

There have been wishes from the public sector that they need tools and researched information with which they can justify and argue their decisions. For instance, how to move towards a circular economy or what it means in general in Finland ja what is the way to go. (H7 academy)

Hiedanranta, a living lab, is a new district area in the city of Tampere and can be understood as a platform for different actors to interact and solve problems via a multidimensional approach. The role for public agencies in research and innovation 
processes in multi-level co-operation was frequently as a moderator between research practices and business needs. For academics, the living lab is a good way to create knowledge; for businesses, the living lab conditions make possible the exploitation of knowledge and the development of profitable solutions. From the quadruple helix point of view, where the perspective is on people, the Hiedanranta living lab is a good example of how government, academics and business can co-operate in making an effort to solve the most challenging social problems and gather knowledge from experimentation along with citizenship.

Hiedanranta. [..] there is lot of research, there is city involved. [..] we have a strategy 'Human

Potential Unlimited' [..] health, society, technology are our cornerstones. (H9 academy)

All interviewees recognised that citizens and the society at large constitute a perspective that is quite hard to take as a part to the interaction. Interests, values and competence differ in many ways, and these are the main problems in the quadruple helix. Also, when creating forums for interaction with citizens, the main question is: who will come and with what kinds of ideas and knowledge base?

In Table 10.2 the views of the interviewees are presented on the base of their roles in the quadruple helix, their understanding of 'responsible', their overall idea about social innovations and their understanding of the 'fourth factor' of the quadruple helix, namely, 'people'. Since RRI as a concept was not recognised by the interviewees (except those from a research institute), a summary of the definition of responsible from three different perspectives is shown: reductionist, i.e., are they using some standards to define or measure responsible innovations; operative, i.e., for whom are they responsible; and substantive, i.e., what are the main contents of responsibility (sustainability).

In a Nordic context, the roles of different actors are mixed. Universities and research institutes are required by law to participate to the development of society and industry "In carrying out their mission, the universities shall promote continuous learning, interact with the surrounding society and promote the social impact of university research findings and artistic activities" (University Act 2009), the municipalities and cities have a legal mission to "advance the well-being of their residents and the vitality of their respective areas, and shall arrange services for their residents in a way that is financially, socially and environmentally sustainable" (Local Government Act 2015). The responsibility in innovation and research activities is defined in a reductionist manner mostly in the context of SDGs. The UN development goals are commonly known and widely accepted as a standard for responsibility. Only in research institute the vocabulary of RRI was familiar.

In more operational term responsibility is defined as in universities other "legal aspects of responsibility" such as a mandate to promote public ethos and bridge other actors in public sector, as integrity of science and critical approach in universities and research institutes. In our case, energy sector in Tampere, the operational definition of energy company was value for money approach since the company is publicly own. On substantial front the responsibility is mostly defined mostly in terms of environmental sustainability, but the social aspects are mentioned as well. Summing up the findings this paper concludes that in Tampere region there is quite 
Table 10.2 The main findings

\begin{tabular}{|c|c|c|c|c|}
\hline Perspective & $\begin{array}{l}\text { ROLE in Quadruple } \\
\text { Helix }\end{array}$ & $\begin{array}{l}\text { Definition of } \\
\text { 'Responsible' }\end{array}$ & $\begin{array}{l}\text { social innovations } \\
\text { are }\end{array}$ & $\begin{array}{l}\text { Role of } \\
\text { 'people' }\end{array}$ \\
\hline Industry & $\begin{array}{l}\text { In energy sector in } \\
\text { Nordic society such } \\
\text { as Finland the roles } \\
\text { are mixed. Part of } \\
\text { the companies are } \\
\text { owned by public } \\
\text { bodies and they are } \\
\text { thus accountable } \\
\text { also for citizens as } \\
\text { 'taxpayers'. In addi- } \\
\text { tion, energy sector is } \\
\text { represented by an } \\
\text { interest group that is } \\
\text { mostly representing } \\
\text { public companies. }\end{array}$ & $\begin{array}{l}\text { Reductionist: } \\
\text { SDGs } \\
\text { Operative: } \\
\text { Taxpayers' } \\
\text { money } \\
\text { Substantial: } \\
\text { Green solutions } \\
\text { for wicked } \\
\text { problems related } \\
\text { to environmen- } \\
\text { tal change }\end{array}$ & $\begin{array}{l}\text { Customer orienta- } \\
\text { tion: } \\
\text { Provide a green } \\
\text { option for customer } \\
\text { with customer }\end{array}$ & $\begin{array}{l}\text { Customer and } \\
\text { taxpayer } \\
\text { (legitimation } \\
\text { trough cus- } \\
\text { tomer } \\
\text { decision) }\end{array}$ \\
\hline $\begin{array}{l}\text { Universities } \\
\text { and research } \\
\text { institutions }\end{array}$ & $\begin{array}{l}\text { In a long-term uni- } \\
\text { versity has a respon- } \\
\text { sibility to work with } \\
\text { (regional) stake- } \\
\text { holders and this is } \\
\text { also mentioned in } \\
\text { legislation. } \\
\text { The research insti- } \\
\text { tutes have by law a } \\
\text { mission to collabo- } \\
\text { rate with industry. }\end{array}$ & $\begin{array}{l}\text { Reductionist: } \\
\text { SDGs', RRI in } \\
\text { research insti- } \\
\text { tute } \\
\text { Operative: } \\
\text { Integrity of sci- } \\
\text { ence and critical } \\
\text { approach } \\
\text { (e.g. towards } \\
\text { financial } \\
\text { maxims) } \\
\text { Substantial: } \\
\text { (environmental) } \\
\text { sustainability } \\
\end{array}$ & $\begin{array}{l}\text { Living lab type } \\
\text { co-operation is a } \\
\text { practical way to } \\
\text { enhance new } \\
\text { knowledge base and } \\
\text { create new solutions }\end{array}$ & $\begin{array}{l}\text { Co-producer } \\
\text { of knowledge } \\
\text { (legitimations } \\
\text { by } \\
\text { participation) }\end{array}$ \\
\hline $\begin{array}{l}\text { Public } \\
\text { agency }\end{array}$ & $\begin{array}{l}\text { To coordinate policy } \\
\text { initiatives including } \\
\text { multiple stake- } \\
\text { holders. } \\
\text { To build and main- } \\
\text { tain infrastructures } \\
\text { for citizen } \\
\text { participation. }\end{array}$ & $\begin{array}{l}\text { Reductionist: } \\
\text { SDGs, gender } \\
\text { issues, reliable } \\
\text { partners (taxes } \\
\text { and salaries } \\
\text { paid) } \\
\text { Operative: } \\
\text { Public ethos } \\
\text { Bridging role } \\
\text { Substantial: } \\
\text { Citizen's partici- } \\
\text { pation in sus- } \\
\text { tainable city } \\
\text { development, } \\
\text { green } \\
\text { innovations }\end{array}$ & $\begin{array}{l}\text { Living labs } \\
\text { Co-creation } \\
\text { Diversity of } \\
\text { participants }\end{array}$ & $\begin{array}{l}\text { Citizen } \\
\text { (legitimisation } \\
\text { as a constitut- } \\
\text { ing member } \\
\text { and through } \\
\text { equality) }\end{array}$ \\
\hline
\end{tabular}

Source: Own elaboration 
strong consensus on the importance of SDGs and the emphasis of the environmental aspect of the responsibility discourse. The role of citizen is mostly framed from the perspective of legitimization. This is regardless of the use of co-vocabulary. Legitimizing role given for a participating citizen is different depending on the institutional perspective used for definition. In business the legitimization comes from customer-oriented approach, in science the main discourse is 'science with society' and for the public sectors the role of citizen is more profound namely citizens are constituting the public actors and thus fundamental for the activities. In public sector the citizen involvement to innovation processes is seen as legitimizing activity as a practice providing an equal access to participate.

\section{Discussion and Conclusion}

By utilising the Tampere region social innovation process in the energy sector within its regional innovation system as a case example, the objective of this paper has been to discuss how the different actors of the regional innovation system perceived their own role and that of other actors in RRI, how they define 'responsible' in the context of RRI, and what is their overall understanding of the social innovations. Accordinlgy, the study draws three important conclusions. First, it is t only the state funded research institute was aware of RRI as a policy concept. However, as in previous studies, in general, this study shows that, even though most organisations are unfamiliar with RRI, they can discuss themes related to responsible research and innovation. RRI is not applied even in a reductionistic manner, as a concept used for describing current activities, since it not generally known.

This paper argues that, from a Quadruple Helix perspective, what new of RRI lies in the following three aspects: democracy, change in knowledge production, and the central focus of the innovation ecosystem. All these aspects were evident in the empirical analyses this chapter. Firstly, democracy was considered important for knowledge production and innovation (Carayannis \& Campbell, 2017; Campbell, 2019). However, the idea of democracy was mostly related to inherited (Nordic) ideology of participation than to overall discussion on innovations. It was considered that involvement of citizens, taxpayers, and customers is an end in itself, and is not only a way of producing something new.

Secondly, changes of the innovation ecosystem towards mode 3 , knowledge production (Carayannis \& Campbell, 2012), were evident in the case of Tampere, as the Quadruple Helix model centres on such Mode 3, illustrated in the case of the joint development platform 'Hiedanranta'.

Thirdly, the Tampere innovation ecosystem is indeed a "fractal, multi-level, multi-modal, multi-nodal, and multi-lateral configurations of dynamic tangible and intangible assets" (Carayannis et al., 2018, p. 148). It is difficult to distinguish the actors from each other, and 'helices' are formed in different levels of the system. For instance, the case of the local energy company shows that it operates in the interfaces of public and private spheres. It is also difficult to distinguish regional and national 
innovations systems since they are overlapping and interconnected. However, it seems that, in sustainable innovation discourse, the European level is almost missing, regardless of multiple funding instruments. Policies are directly connected to SDGs and discussion around environmental change, green innovation, and green economy.

What can be learned about the role of research and social innovations in the case of Tampere? All stakeholder citizens are seen as important actors and are considered co-producers ('with' society, public engagement). However, the dominant discourse still provides a place for citizens as legitimisers rather than active participants. The role of legitimiser can be seen from the perspective of local democracy (political legitimisation), customer-centred services (consumer legitimisation), and public services (taxpayer, value for money).

Finally, as a policy implication it is learned that pragmatic inquiry is useful in coping with social innovations. There are many ways to approach global problems such as climate change, and there can be many solutions to energy sector challenges. As pragmatists, Mead and Dewey taught that democratic solutions are opening arrangements enabling social participation in reflection on the chances to solve collective problems (Dewey, 1988). Thus, by including citizens' voices in the collective problem dilemma, decision-making processes entail a deeper commitment of actors' governance and social action becomes a creative process to be legitimised. Here, the importance given to having a shared understanding on policy concepts, such as responsible research and innovation, is key to the final social solutions in democratic societies.

Acknowledgements This book chapter is based on the technical report results of the project RRIL Responsible Research \& Innovation Learning, which is co-funded with support from the European Commission. RRIL-project $\mathrm{n}^{\circ}$ 2018-1-ES01-KA203-050890. The contents of the book chapter reflect only the authors' views. The Commission cannot be held responsible for any use which may be made of the information contained therein. We are very grateful to the respondents for their constructive and fruitful cooperation in the preparation of the technical report.

\section{Appendix 1 Interviewees}

\section{Higher Education (Academia)}

Aalto Pami, Professor, International Relations, Energy Politics, Tampere University, Faculty of Management and Business.

Kujala Johanna, Professor and Vice-Dean of Research, Tampere University, Faculty of Management and Business.

Pilvi Taru, Innovation Leader, Tampere University.

Raatikainen Saana, Tampere University, Environmental Co-ordinator and Chairman of the Board of Energy of Lempäälä. 


\section{Public Research Institutes (Academy)}

Nieminen Mika, Leading Researcher, VTT Technical Research Centre of Finland Ltd.

Vainio Terttu, Special Researcher, VTT Technical Research Centre of Finland Ltd.

\section{City and Region (Government or Public Agency)}

Myllykangas Päivi, Innovation Leader, Council of Tampere Region.

Vanhanen Tuomas, City of Tampere, Smart Tampere, Sustainable Tampere 2030, Project manager.

Vehviläinen Maarit, City of Tampere, Smart Tampere, Sustainable Tampere 2030, Project manager.

\section{Business (Industry)}

Muurinen Pasi, Vice President, Customer Relations, Tampereen sähkölaitos Oy.

Kulmala Harri, Chief Executive Officer, Dimecc Oy.

Boström Anna-Stiina, Executive director, FinDHC,

[FinDHC is the Finnish Heating and Cooling Association, which is a non-profit organization, the mission of which is to improve awareness and recognition of district energy.]

\section{References}

Appio, F. P., Frattini, F., Petruzzelli, A. M., \& Neirotti, P. (2021). Digital transformation and innovation management: A synthesis of existing research and an agenda for future studies. Journal of Product Innovation Management, 38(1), 4-20. https://doi.org/10.1111/jpim.12562

Asante, K., Owen, R., \& Williamson, G. (2014). Governance of new product development and perceptions of responsible innovation in the financial sector: Insights from an ethnographic case study. Journal of Responsible Innovation, 1(1), 9-30. https://doi.org/10.1080/23299460.2014. 882552

Bauer, A., Bogner, A., \& Fuchs, D. (2021). Rethinking societal engagement under the heading of responsible research and innovation: (novel) requirements and challenges. Journal of Responsible Innovation, 1-22. https://doi.org/10.1080/23299460.2021.1909812

Bies, R. (2014). At the crossroads of trust and distrust: Skepticism and ambivalence toward business. In J. Harris, B. Moriarty, \& A. Wicks (Eds.), Public trust in business (pp. 86-115). Cambridge University Press. https://doi.org/10.1017/CBO9781139152389.00 
Blok, V., Hoffmans, L., \& Wubben, E. (2015). Stakeholder engagement for responsible innovation in the private sector: Critical issues and management practices. Journal on Chain and Network Science, 15, 147-164.

Boschma, R. (2005). Proximity and innovation: A critical assessment. Regional Studies, 39(1), 61-74. https://doi.org/10.1080/0034340052000320887

Bozeman, B., \& Sarewitz, D. (2011). Public value mapping and science policy evaluation. Minerva, 49(1), 1-23. https://doi.org/10.1007/s11024-011-9161-7

Burchell, K. (2015). Factors affecting public engagement by researchers: Literature review. Policy Studies Institute, . Retrieved on April 20, 2021 from https://wellcome.org/sites/default/files/ wtp060036.pdf.

Burget, M., Bardone, E., \& Pedaste, M. (2017). Definitions and conceptual dimensions of responsible research and innovation: A literature review. Science and Engineering Ethics, 23(1), 1-19. https://doi.org/10.1007/s11948-016-9782-1

Cai, Y., \& Etzkowitz, H. (2020). Theorizing the triple helix model: Past, present, and future. Triple Helix, 6, 1-38. https://doi.org/10.1163/21971927-bja10003

Cai, Y., Ferrer, B. R., \& Lastra, J. L. M. (2019). Building university-industry co-innovation networks in transnational innovation ecosystems: Towards a transdisciplinary approach of integrating social sciences and artificial intelligence. Sustainability, 11(17), 1-23. https://doi. org/10.3390/su11174633

Campbell, D. F. J. (2019). Global quality of democracy as innovation enabler: Measuring democracy for success [text]Palgrave Studies in Democracy, Innovation, and Entrepreneurship for Growth (pp. LI, 509 p. 564 illus., 526 illus. in color). https://doi.org/10.1007/978-3-31972529-1.

Carayannis, E. G., \& Campbell, D. F. J. (2009). 'Mode 3' and 'quadruple helix': Toward a 21st century fractal innovation ecosystem. International Journal of Technology Management, 46 (3/4), 201-234. https://doi.org/10.1504/IJTM.2009.023374

Carayannis, E. G., \& Campbell, D. F. J. (2012). Mode 3 knowledge production in quadruple helix innovation systems (Vol. 7, pp. 1-63). Springer.

Carayannis, E. G., \& Campbell, D. F. J. (2017). Quadruple and quintuple helix innovation systems and mode 3 knowledge production. In E. G. Carayannis, D. F. J. Campbell, \& M. P. Efthymiopoulos (Eds.), Handbook of cyber-development, cyber-democracy, and cyber-defense (pp. 1-19). Springer International Publishing.

Carayannis, E. G., Grigoroudis, E., Campbell, D. F. J., Meissner, D., \& Stamati, D. (2018). The ecosystem as helix: An exploratory theory-building study of regional co-opetitive entrepreneurial ecosystems as quadruple/quintuple helix innovation models. R\&D Management, 48(1), 148-162. https://doi.org/10.1111/radm.12300

Carrier, M., \& Gartzlaff, M. (2020). Responsible research and innovation: Hopes and fears in the scientific community in Europe. Journal of Responsible Innovation, 7(2), 149-169. https://doi. org/10.1080/23299460.2019.1692571

Castells, M., \& Himanen, P. (2002). The information society and the welfare state. The Finnish model. Oxford University Press.

Chatfield, K., Borsella, E., Mantovani, E., Porcari, A., \& Stahl, B. C. (2017). An investigation into risk perception in the ICT industry as a core component of responsible research and innovation. Sustainability, 9(8), 1424.

Christensen, M. V., Nieminen, M., Altenhofer, M., Tangcoigne, E., Mejlgaard, N., Griessler, E., \& Filacek, A. (2020). What's in a name? Perceptions and promotion of responsible research and innovation practices across Europe. Science and Public Policy, 47(3), 360-370. https://doi.org/ 10.1093/scipol/scaa018

Dahlman, C. J., Routti, J., \& Ylä-Antilla, P. (2006). Finland as a knowledge economy: Elements of success and lessons learned. World Bank. Retrieved on May 14 2021, from https:// openknowledge.worldbank.org/handle/10986/7138. 
De Oliveira Monteiro, S. P., \& Carayannis, E. G. (2017). The quadruple innovation helix nexus: A smart growth model, quantitative empirical validation and operationalization for OECD countries. Palgrave Macmillan.

de Saille, S. (2015). Innovating innovation policy: The emergence of 'responsible Researchand innovation'. Journal of Responsible Innovation, 2(2), 152-168.

Dewey, J. (1988). In J. Boydston (Ed.), A theory of valuation. The later works of John Dewey, 1925-1953 (Vol. 13, pp. 1938-1939). Southern Illinois University Press. 13.

Dreyer, M., Chefneux, L., Goldberg, A., Von Heimburg, J., Patrignani, N., Schofield, M., \& Shilling, C. (2017). Responsible innovation: A complementary view from industry with proposals for bridging different perspectives. Sustainability, 9(10), 1719.

Etzkowitz, H., \& Leydesdorff, L. (1995). The triple helix-university-industry-government relations: A Laboratory for Knowledge-Based Economic Development. EASST review, 14, 14-19. Retrieved on April 4, 2021 from. http://www.leydesdorff.net/th1/index.htm.

European Commission. (2001). European governance: A white paper. COM (2001) 428 final, European Commission, Brussels. Retrieved on May 20, 2021 from https://op.europa.eu/en/ publication-detail/-/publication/11c3e337-9cf5-4603-a518-cacb77207e3b/language-en.

European Commission. (2009). Preparing Europe for a new renaissance: A strategic view of the European research area: first report of the European Research Area Board 2009 (KI-NA23905-EN-C). Retrieved on April 20, 2021 from http://bookshop.europa.eu.

Hennen, L. (2013). Parliamentary technology assessment in Europe and the role of public participation. In K. O'Doherty \& E. Einsiedel (Eds.), Public engagement and emerging technologies (pp. 27-44). UBC Press.

Herrera, M. E. B. (2015). Creating competitive advantage by institutionalizing corporate social innovation. Journal of Business Research, 68(7), 1468-1474.

Karhunmaa, K. (2019). Attaining carbon neutrality in Finnish parliamentary and city council debates. Futures, 109, 170-180.

Lundvall, B.-Å. (Ed.). (1992). National systems of innovation: Towards a theory of innovation and interactive learning. Pinter Publishers.

Macnaghten, P. (2016). Responsible innovation and the reshaping of existing technological trajectories: The hard case of genetically modified crops. Journal of Responsible Innovation, 3(3), 282-289. https://doi.org/10.1080/23299460.2016.1255700

Martinuzzi, A., Blok, V., Brem, A., Stahl, B., \& Schönherr, N. (2018). Responsible research and innovation in industry-Challenges, insights and perspectives. Sustainability, 10(3), 1-9.

Miettinen, R. (2013). Innovation, human capabilities, and democracy: Towards an enabling welfare state. Oxford University Press.

Miller, K., McAdam, R., \& McAdam, M. (2018). A systematic literature review of university technology transfer from a quadruple helix perspective: Toward a research agenda. $R \& D$ Management, 48(1), 7-24. https://doi.org/10.1111/radm.12228

Nicholls, A., Simon, J., \& Gabriel, M. (2015). Introduction: Dimensions of social innovation. In A. Nicholls, J. Simon, \& M. Gabriel (Eds.), New Frontiers in social innovation research. Palgrave Macmillan. https://doi.org/10.1057/9781137506801_1

OECD. (2017). OECD Reviews of Innovation Policy: Finland 2017, OECD Reviews of Innovation Policy, OECD Publishing, Paris, Retreived on April 10, 2021 from https://doi.org/10.1787/ 9789264276369-en.

Owen, R., Macnaghten, P., \& Stilgoe, J. (2012). Responsible research and innovation: From science in society to science for society, with society. Science and Public Policy, 39(6), 751-760.

Owen, R., \& Pansera, M. (2019). Responsible innovation and responsible research and innovation. In D. Simon, S. Kuhlmann, J. Stamm, \& W. Canzler (Eds.), Handbook on science and public policy (pp. 26-48). Edward Elgar Publishing. https://doi.org/10.4337/9781784715946

Owen, R., Stilgoe, J., Macnaghten, P., Gorman, M., Fisher, E., \& Guston, D. (2013). A framework for responsible innovation. In R. Owen, J. Bessant, \& M. Heintz (Eds.), Responsible innovation: Managing the responsible emergence of science and innovation in society. John Wiley.

Polanyi, M. (1962). The republic of science. Minerva, 1(1), 54-73. 
Ritala, P., \& Hurmelinna-Laukkanen, P. (2009). What's in it for me? Creating and appropriating value in innovation-related coopetition. Technovation, 29(12), 819-828.

Schienstock, G., \& Hämäläinen, T. (2001). Transformation of the Finnish innovation system. A network approach. Sitra reports series 7. Hakapaino Oy.

Şener, S., \& Sarıdoğan, E. (2011). The effects of science-technology-innovation on competitiveness and economic growth. Procedia-Social Behav. Sci., 24, 815-828.

Stilgoe, J., Owen, R., \& Macnaghten, P. (2013). Developing a framework for responsible innovation. Research Policy, 42(9), 1568-1580. https://doi.org/10.1016/j.respol.2013.05.008

Strand, R., Spaapen, J., Bauer, M. W., Hogan, E., Revuelta, G., \& Stagl, S. (2015). Indicators for promoting and monitoring responsible research and innovation. In Report from the expert group on policy indicators for responsible research and innovation. European Commission. Retrieved April 20, 2021 from https://ec.europa.eu/research/swafs/pdf/pub_rri/rri_indicators_ final_version.pdf

TEM. (2014). Tÿ̈- ja elinkeinoministeriö. Yrityskatsaus 2014. Murroksia ja uudistumista. Retrieved on May 06, 2021 from https://tem.fi/documents/1410877/2859687/Yrityskatsaus $+2014+02102014$.pdf

TEM. (2018). Työ- ja elinkeinoministeriö. Pk -yritysbarometri syksy 2018. Retrieved on May 06, 2021 from https://tem.fi/artikkeli/-/asset_publisher/pk-yritysbarometri-yritysten-kasvuunrahoituksen-pullonkauloihin-ja-digitalisaatioon-tarvitaan-edelleen-toimia

TEM. (2020). Työ- ja elinkeinoministeriön julkaisuja 2020:5. Teknologia, investoinnit, rakennemuutos ja tuottavuus-Suomi kansainvälisessä vertailussa. Retrieved from May 06, 2021 from http://urn.fi/URN:ISBN:978-952-327-492-1

Tilastokeskus. (2005). Retrieved on May 02, 2021 from http://www.stat.fi/tup/tietoaika/ta_01_05_ mallimaa.html

Tilastokeskus. (2017a). Retrieved on April 25, 2021 from http://www.stat.fi/til/slv/2017/11/slv_ 2017_11_2017-12-29_tie_001_fi.html

Tilastokeskus. (2017b). Retrieved on April 18, 2021 from http://www.stat.fi/tietotrendit/artikkelit/ 2017/ulkomaankaupan-yritysrakenne-katsaus-yhdistaa-tavarat-ja-palvelut/\#maincontent

Tilastokeskus. (2018). Retrieved on April 18, 2021 from https://www.stat.fi/til/slv/2018/10/slv 2018_10_2018-11-29_tie_001_fi.html

Sturgis, P., \& Nick, A. (2004). Science in society: Re-evaluating the deficit model of public attitudes. Public Understanding of Science, 13, 55-54.

von Schomberg, R. (2001). Introduction: Towards responsible research and innovation in the information and communication technologies and security technologies fields. In R. V. Schomberg (Ed.), Towards responsible research and innovation in the information and communication technologies and security technologies fields (pp. 7-16). Publications Office of the European Union.

von Schomberg, R. (2011). Prospects for technology assessment in a framework of responsible research and innovation. In M. Dusseldorp \& R. Beecroft (Eds.), Technikfolgen abschätzen lehren: Bildungspotenziale transdisziplinärer Methoden (pp. 39-61). Vs Verlag.

von Schomberg, R., \& Blok, V. (2019). Technology in the age of innovation: Responsible innovation as a new subdomain within the philosophy of technology. Philosophy \&Technology, 3519. https://doi.org/10.1007/s13347-019-00386-3

Yaghmaei, E. (2018). Responsible research and innovation key performance indicators in industry: A case study in the ICT domain. Journal of Information, Communication and Ethics in Society, 16(2), 214-234. https://doi.org/10.1108/JICES-11-2017-0066

Valtioneuvosto. (2019). Retrieved on April 24, 2021 from https://julkaisut.valtioneuvosto.fi/ bitstream/handle/10024/161271/TEM_1_2019_Suomen\%20kilpailukyvyn\%20ja_.pdf

Zhao, Y., Fautz, C., Hennen, L., Srinivas, K. R., \& Li, Q. (2015). Public engagement in the governance of science and technology. In M. Ladikas, S. Chaturvedi, Y. Zhao, \& D. Stemerding (Eds.), Science and technology governance and ethics: A global perspective from Europe, India and China (pp. 39-51). Springer International Publishing. 
Yohannes Mehari holds a Ph.D. in Administrative Sciences from Tampere University, Finland. He received the Best Dissertation Award in 2017 from the Finnish Association of Administrative Studies. He is a university instructor at the Faculty of Management and Business, and member of the Higher Education Group (HEG) in Tampere University. He has worked as Coordinator of an international Project called "Building Institutional Capacity in Leadership and Management of Ethiopian Universities (LMEU)". Currently, he is also serving as institutional coordinator of Responsible Research and Innovation Learning (RRIL), which is funded with support from the European Commission. Within the field of higher education, his research interest and expertise include higher education governance, leadership and management, funding, quality, capacity development and professional development. Yohannes has participated and presented papers in various International Conferences.

Elias Pekkola, PhD is University Lecturer and the Head of the Administrative Studies unit in the Faculty of Management and Business, Tampere University, Finland. Pekkola's publications include several articles and books on public administration and policy, academic work, the academic profession, careers, and HR policy. Pekkola also serves as an academic coordinator of the Nordic Master Programme in Innovative Governance and Public Management. He has acted in various expert roles in Finland and in international projects on academic work, careers, and higher education policy.

Jonna Hjelt, $\mathrm{PhD}$ is University Researcher at the Faculty of Management and Business, Tampere University, Finland. Hjelt's research interests are in the field of technological development, innovations, learning organizations and systemic interaction. She made her dissertation in the field of large companies and in particular R\&D departments direct and indirect means to promote company's strategic goals-R\&D departments systemic interaction.

Yuzhuo Cai, PhD is Senior Lecturer and Adjunct Professor of higher education administration at the Faculty of Management and Business, Tampere University, Finland. He is a member of the Executive Committee of Triple Helix Association and a co-editor-in-chief of the Triple Helix: A Journal of University-Industry-Government Innovation and Entrepreneurship. He is also a co-director of the Sino-Finnish Education Research Centre jointly coordinated by Tampere University and Beijing Normal University. His main research areas are higher education policy and management, innovation studies and internationalisation of higher education, with over 100 scholarly publications.

Jari Stenvall, $\mathrm{PhD}$ is Professor in public management at Tampere University, Finland. He has published widely in the area of learning and innovation, change management, trust, organizational reforms, service innovations, and the use of information technology in organizations. He is a member of the national team with the purpose to develop Finnish public management.

Francisco Javier Ortega-Colomer, $\mathrm{PhD}$ is Assistant Professor in the Department of Business Management at the University of Valencia. His research interests are about the inclusion of the environmental dimension in companies' strategies (eco-innovation). In addition, he has studied university-industry relationships and cooperation between agents of the innovation system in various contexts, participating in regional, national, and European projects. 
Open Access This chapter is licensed under the terms of the Creative Commons Attribution 4.0 International License (http://creativecommons.org/licenses/by/4.0/), which permits use, sharing, adaptation, distribution and reproduction in any medium or format, as long as you give appropriate credit to the original author(s) and the source, provide a link to the Creative Commons license and indicate if changes were made.

The images or other third party material in this chapter are included in the chapter's Creative Commons license, unless indicated otherwise in a credit line to the material. If material is not included in the chapter's Creative Commons license and your intended use is not permitted by statutory regulation or exceeds the permitted use, you will need to obtain permission directly from the copyright holder. 